\author{
Michele Asmar Fanini \\ Universidade de São Paulo
}

\title{
Júlia Lopes de Almeida teatróloga: apontamentos sobre a peça inédita "O Caminho do Bem"
}

\begin{abstract}
Resumo: Considerada uma das mais expoentes prosadoras da "belle époque tropical", Júlia Lopes de Almeida (1862-1934) revelou-se, a despeito do gênero literário que a consagrou, detentora de uma inegável versatilidade estilística. Quanto a isso, suas incursões pelas artes dramáticas são um inequívoco exemplo: além de haver publicado os volumes $A$ Herança (1909) e Teatro (1917), a escritora deixou algo em torno de uma dezena de textos teatrais inéditos e não encenados, todos eles disponíveis, sob a forma de documentos autógrafos e/ou datiloscritos, em seu acervo particular, mantido por Claudio Lopes de Almeida, seu neto. Diante da magnitude do legado em questão, o presente artigo estabelece como recorte analítico privilegiado a peça inédita "O Caminho do Bem", a partir da qual tencionamos contribuir, à luz das imbricações entre arte e gênero/sexo, não apenas para a fortuna crítica da escritora, mas para aqueles estudos dedicados à pavimentação de lacunas que a historiografia literária brasileira ainda abriga.
\end{abstract}

Palavras-chave: Júlia Lopes de Almeida; manuscritos inéditos; literatura brasileira; artes dramáticas; gênero.

Copyright (c) 2013 by Revista Estudos Feministas.

' Este artigo é resultado parcial da pesquisa de pós-doutorado que desenvolvo no Instituto de Estudos Brasileiros da USP (IEB), para a qual conto com a supervisão dos Profs. Drs. Marcos Antonio de Moraes e Ana Paula C. Simioni, bem como com o financiamento da FAPESP. ${ }^{2}$ À exceção de A falência (1901), A isca (1922) e Pássaro tonto (1934), Júlia Lopes publicou seus romances, primeiramente, sob a forma de folhetim, procedimento bastante comum no período. São eles: Memórias de Marta (1889); A família Medeiros (1892); A viúva

\section{Introdução'}

Tendo obtido significativa notabilidade e prestígio como prosadora, ${ }^{2}$ reconhecimento este reconvertido em sua inclusão naquele seleto rol formado pelos escritores de renome da literatura do entresséculos (XIX para o XX), ${ }^{3}$ Júlia Lopes de Almeida (1862-1934) revelou-se, acima de tudo, detentora de uma inegável versatilidade estilística. Tal afirmação assenta-se no fato de que, muito embora tenha se consagrado como romancista, a escritora carioca também se dedicou, ao longo de seu percurso artístico, à produção de poemas, ${ }^{4}$ crônicas, contos, ensaios e até mesmo peças teatrais, investidas essas reveladoras, a um só tempo, de sua verve criativa e do quanto sua obra segue, em larga medida, inexplorada. Para se ter uma ideia, considerando-se apenas a 
Simões (1897; A intrusa (1908); Cruel amor (1911); Correio da roça (1913); A casa verde (1932). Como contista, publicou Contos infantis (1886), escrito em parceria com sua irmã, Adelina Lopes Vieira; Traços e iluminuras (1887); Ânsia eterna (1903); Histórias do nossa terra (1907) e Era uma vez (1917). Além disso, as artes dramáticas também receberam a contribuição de Júlia Lopes: $A$ herança (1909) e Teatro, volume composto por três textos teatrais: "Quem não perdoa", "Doidos de amor" e "Nos jardins de Saul". Por sua vez, grande parte das crônicas que publicou nos jornais da época foi condensada nos volumes Livro das noivas (1896); Livro das donas e donzelas (1906) e Eles e Elas (1910). Júlia Lopes também publicou $A$ árvore (1916), coletânea de contos e poemas, em parceria com seu filho Afonso Lopes de Almeida; Jornadas no meu país (1920), registros sobre a viagem que fez ao Sul do Brasil (o livro traz ilustrações de seu filho caçula, Albano Lopes de Almeida); e Jardim florido, jardinagem (1922), além de ensaios, conferências e traduções.

${ }^{3}$ Brito BROCA, 1979; Lúcia MIGUELPEREIRA, 1988; Nadilza MOREIRA, 2003; Maria de Lourdes ELEUTÉRIO, 2005.

${ }_{4}^{4}$ Júlia Lopes estreou formalmente no universo literário em 1881, ano da publicação, na Gazeta de Campinas, de sua primeira crônica intitulada Gemma Cunibert. Porém, seu interesse em "fazer da pena o seu ofício" aflorou precoce mente, e o gênero ao qual se dedicava, quando moça, era a poesia (Cf. Leonora DE LUCA, 1999 Rosane SALOMONI, 2005, p. 24). ${ }^{5}$ Michelle PERROT, 2005. Como lembra Perrot (2005, p. 9), "a irrupção de uma presença e de uma fala femininas em locais que Ihes eram até então proibidos, ou pouco familiares, é uma inovação do século XIX que muda o horizonte sonoro. Subsistem, no entanto, muitas zonas mudas e, no que se refere ao passado, um oceano de silêncio, ligado à partilha desigual dos traços, da memória e ainda mais, da História, este relato sua ałuação como dramaturga, afora os volumes que chegou a publicar, quais sejam, $A$ herança (1909) e Teatro (1917), Júlia Lopes produziu algo em torno de uma dezena de textos teatrais que, nunca editados, seguem inexplorados, sob a forma de documentos autógrafos e datiloscritos, todos eles disponíveis em seu acervo particular, mantido pelo seu neto, Claudio Lopes de Almeida.

Em vista do exposto, o presente artigo tem o propósito de iluminar as contribuições de Júlia Lopes de Almeida para a dramaturgia brasileira, intenção essa que, em função da magnitude do legado em questão, requer a calibragem de nosso escopo analítico. Assim sendo, buscaremos restringir a análise à peça inédita "O Caminho do Bem" - selecionada em virtude do andamento do trabalho de transcrição a que o corpus documental fora submetido -, a partir da qual pretendemos contribuir, à luz das imbricações entre arte e gênero/sexo, não apenas para a fortuna crítica da escritora, mas também para aqueles estudos dedicados à pavimentação de lacunas que a historiografia literária brasileira ainda abriga, ou, para falar como Michelle Perrot, ${ }^{5}$ a fazer ouvir "os silêncios da história".

\section{Do proscênio como preâmbulo ao enredo descortinado}

"O Caminho do Bem" (Figura 1). Esse foi o nome escolhido por Júlia Lopes para intitular o drama em Hum ato, datado de 25 de julho de 1883, quando a escritora contava apenas 21 anos e residia com sua família na cidade de Campinas. Em fina sintonia com o contexto em que foi concebida, marcado por aquele conjunto de transformações que redundariam, poucos anos depois, na bancarrota da ordem escravocrata e em sua gradual substituição pelo modelo de sociedade fundamentado no trabalho livre, a peça conta com a presença de cinco personagens, quais sejam, Clotilde, "mãe zelosa" da jovem Laura, ambas a compor o que poderíamos denominar de "núcleo feminino" da ação e a oferecer uma espécie de retrato (ainda que parcial) da família burguesa do Oitocentos; Gama, professor particular desta última; a criada Zina, presença quase figurativa; e Gustavo, filho de uma escrava, para cuja aparição foram reservadas as últimas linhas da trama.

O enredo, que será retomado mais pormenorizadamente ao longo do texto, tem sua dinâmica extraída dos afazeres deveras comezinhos de uma família abonada, flagrados, sobretudo, a partir do relacionamento entre mãe e filha. Apesar de retratar um único dia de convívio familiar, que coincide com o aniversário de nove anos de Laura, a protagonista, o drama é saturado de referências à educação 
que, por muito tempo, "esqueceu" as mulheres, como se, por serem destinadas à obscuridade da reprodução, inenarrável, elas estivessem fora do tempo, ou ao menos fora do acontecimento.

6 Maria Thereza Caiuby BERNARDES, 1989, p. 23.

7 Júlia Lopes de ALMEIDA, 1883 p. 3.

${ }^{8}$ Vânia Carneiro de CARVALHO, 2008, p. 21.

\footnotetext{
${ }^{9}$ Nas palavras de Edmond Goblot, "les métiers manuels en général, même si l'outil est aussi léger qu'une plume ou une aiguille. sont au-dessous de sa dignité dès qu'ils sont la main qui exécute non l'esprit qui conçoit et la volonté qui commande" (1930, p. 24).
}

feminina, ao ethos burguês oitocentista e à escravidão, índices estes a fornecer uma "pintura" do modus vivendi da sociedade brasileira fin-de-siècle.

O eixo temático a articular o entrecho é o processo de aprendizagem a que Laura é submetida: por meio da figura de um preceptor, a jovem recebe uma educação esmerada, sopesada pelos valores morais e éticos que lhe são sutilmente transmitidos por Clotilde, personagem imbuída, assim como Gama, de certa "missão civilizatória", a ilustrar, exemplarmente, aqueles discursos, então em voga, de teor positivista, segundo os quais à mulher caberia a "dignificação da família, da nação e do mundo". ${ }^{6}$ Tais ensinamentos, ao final do drama, são uma das peças-chave ou, mais propriamente, um dos polos a fomentar um jogo marcado pela "encenação dos contrastes", de modo tal que à "herança da escravidão", que Gustavo personifica, antepõe-se a educação, esta sim, apresentada como a única via possível de condução "das almas açoitadas" ao "caminho do bem".

As cenas transcorrem, quase que integralmente, na sala de estudos da residência de Clotilde, cômodo elegante, tal como o descreve a teatróloga no parágrafo de abertura do texto teatral:

Sala de estudo mobiliada com toda a elegância. Portas laterais. Ao fundo, porta e janelas para o jardim. À direita do espectador, embaixo, uma mesa com livros, tinteiro, papel e cadeiras em volta da mesma. À esquerda, mesinha de costura com um bordado, ao lado desta uma poltrona com um banquinho de pés. É dia. ${ }^{7}$

Em consonância com o modelo burguês de residência do século XIX - batizado com o epíteto de "casa moderna" e caracterizado pelo elevado grau de especialização de suas áreas constitutivas (públicas, privadas e de serviço) -, a descrição do cenário da peça permite-nos, de saída, situar as personagens que ali residem em termos de prestígio e status. Tal como assinala Vânia Carneiro de Carvalho, a apresentação do cômodo, bem guarnecido e elegante, "expressa formalmente a situação social de seu proprietário". ${ }^{8}$

Ainda em relação ao cenário, outro aspecto digno de nota é a referência a certos itens do mobiliário, tais como, de um lado, livros, tinteiro e papel e, de outro, o bordado disposto sobre a mesinha de costura, a qual, no decorrer da trama, se descobre não somente pertencer a Clotilde, como ser seu principal afazer, interrompido apenas esporadicamente. Mesmo que não tenha sido feita de modo intencional, a disposição dos objetos parece retraduzir, em termos espaciais, a distância social existente entre o "domínio" das "coisas mentais" e o das "atividades estritamente manuais", aqui representadas pelos "trabalhos de agulhas". 
Figura 1. Frontispício original do texto teatral de "O Caminho do Bem"

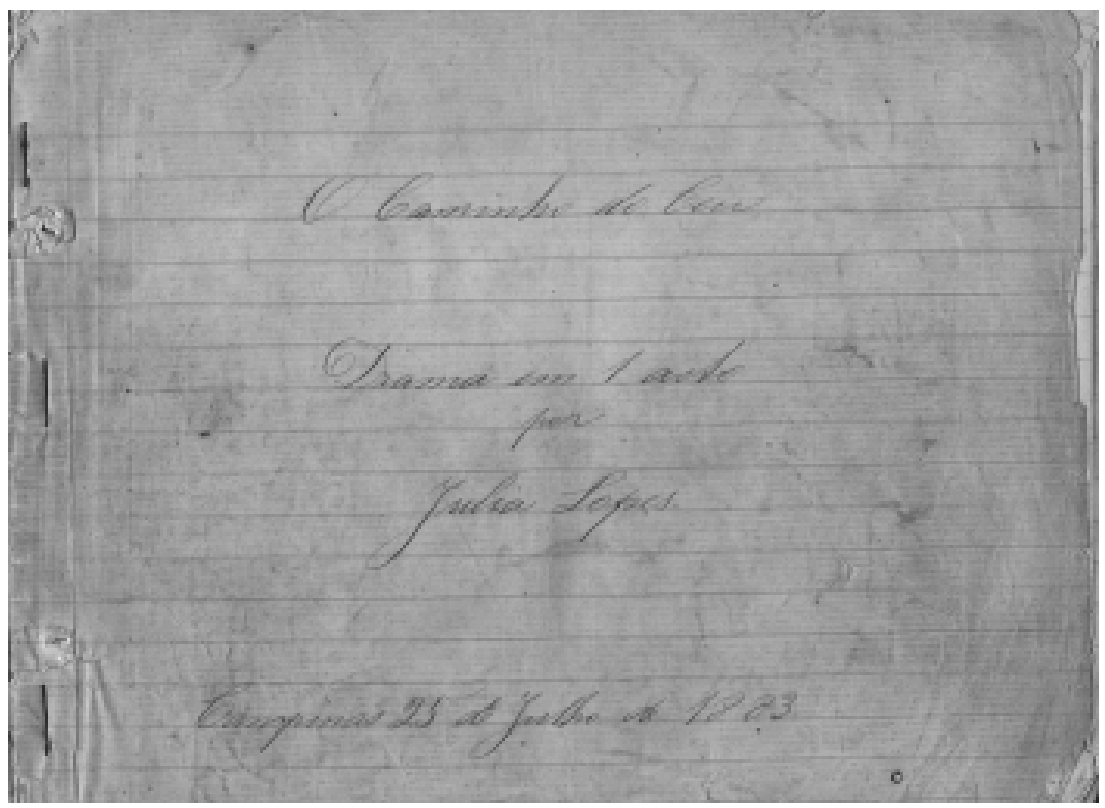

Fonte: Acervo Júlia Lopes de Almeida, sob a guarda de Claudio Lopes de Almeida.

10 Vânia Carneiro de CARVALHO, 2008.

11 Ana Paula C. SIMIONI, 2010. No artigo "Bordado e transgressão: questões de gênero na arte de Rosana Paulino e Rosana Palazyan" (2010), Simioni problematiza a "hierarquia" existente entre os gêneros artísticos, com vistas a historicizar o atrelamento essencializado das artes aplicadas ao gênero feminino, assim como o estigma por estas carreado, lexicalmente ratificado, seja sob o rótulo de "artes menores", seja por meio de seu sinônimo, o termo "artesanato", ambos inequívocos demarcadores de seu distanciamento em relação às "grandes artes", por sua vez, "definidas como todas aquelas baseadas no disegno: a pintura, a escultura e a arquitetura".

12 CARVAlHO, 2011.

${ }^{13}$ SIMIONI, 2010, p. 4.
Além disso, tal apresentação visual "polarizada" abriga uma outra espécie de clivagem, protagonizada pelos arranjos entre "gênero e artefato", ${ }^{10}$ de acordo com a qual, e como bem sintetizado na expressão gendered activities, as "artes aplicadas" e o "universo feminino" comporiam os dois lados de uma equivalência apreendida como "natural", "evidente"," assim como os "objeto[s] associado[s] ao trabalho intelectual" aludiriam ao "gênero masculino". ${ }^{12}$ Aliás, o bordado, ao trazer incrustadas as marcas do gênero feminino, remete-nos àquele "círculo pernicioso" identificado por Simioni, que, forjado no decorrer do século $\mathrm{XIX}$, apreendia as mulheres "como seres intelectualmente inferiores",

[...] capazes de realizar apenas uma arte feminina, ou seja, obras menos significativas do que aquelas feitas pelos homens "geniais", como as grandes telas e/ou as esculturas históricas (GARB, 1989). Gêneros outrora valorizados, como a tapeçaria e o bordado, centrais durante a Idade Média, passaram, ao longo da Idade Moderna, a comportar duas cargas simbólicas negativas: a do trabalho "feminino", logo inferior, e a do trabalho manual, a cada dia mais desqualificado. ${ }^{13}$ 
14 CARVAlHo, 2008, p. 76 Contanto que não transcendesse os limites do diletantismo, o ato de coser era apreendido como fonte feminina de disciplinamento mental e físico, de modo que se uma dona de casa burguesa se deixasse surpreender "tirant l'aiguille dans un salon, - le geste est joli et fait valoir des mains fines, des doigts délicats aux ongles soignés - c'est pour une inutile broderie, une tapisserie superflue ou pour les pauvres" (GOBLOT, 1930 , p. 45). Sobre o assunto, ver também CARVALHO, 2008, 2011.

15 CARVALHO, 2008, p. 68-78. A esse respeito, Carvalho assinala que "todos os espaços da casa deveriam receber uma atenção especial na sua ornamentaçấo. A maneira mais comum era a confecção de trabalhos manuais. Com eles atestava-se a presença cuidadosa e amorosa da dona de casa. Para os segmentos sociais menos abastados podia-se recorrer a um verdadeiro sistema de toalhinhas rendadas" (CARVALHO, 2008, p. 69) ${ }^{16} \mathrm{GORDON}$ citado por CARVALHO, 2008, p. 76.

${ }^{17} \mathrm{O}$ que nos permite ao menos sustentar tal colocação é o fato de os livros, o tinteiro e o papel representarem o arsenal pedagógico utilizado por Gama, sendo as aulas particulares por ele ministradas ilustrativas do tipo de educacão transmitido às moças de famílias abonadas do Oitocentos, cujos propósitos moralizantes reiteravam o processo mesmo de construção simbólica do que se entendia, à época, por "feminino" (por meio da reprodução dos qualificativos tidos como inatos, condizentes ao devir mulher).

${ }^{18}$ CARVALHO, 2008, p. 22.

19 CARVALHO, 2008, 27-28, grifos meus.
Não por acaso, o "trabalho manual doméstico" fora incluído no ideário vitoriano como fonte feminina de "disciplinamento do corpo e do espírito" e "ócio moralmente valorizado", ${ }^{4}$ figurando como item indispensável na lista de atividades que uma esposa exemplar deveria executar, estando de tal forma inscrito na tradição artesanal feminina, que os frutos daí provenientes, destinados, a um só tempo, à ornamentação pessoal e à decoração dos ambientes da casa (nidificação), promoviam uma espécie de "síntese" entre o corpo feminino e aqueles espaços que recebiam sua "demão", mais propriamente, um "embaralhamento" das fronteiras que cindiam os domínios do "uso pessoal" e do "uso doméstico" dos artefatos e adereços confeccionados, a ponto de comprometerem a distinção mesma entre as mulheres e o lar. ${ }^{15}$

Se alguém quisesse parecer tanto atarefado quanto refinado, era especialmente apropriado ser vista trabalhando com ornamentação ou obra de decoração [...]. O trabalho decorativo e atividades artísticas correlatas eram aceitáveis, pois elas eram mais um artesanato 'leve' do que 'belas artes', sérias; eram passatempos amadores mais do que profissionais, e eram adequadas ao ambiente doméstico, que não era uma esfera de atividade profissional. ${ }^{16}$

Ainda que a "roupagem" do elegante cômodo em questão, por si só, não nos autorize a proceder a generalizações acerca das correspondências entre "gênero" e "artefato" - some-se a tal ponderação o fato de, tal como mostraremos adiante, os itens que aludem ao "domínio do espírito" (ou, nas palavras de Simioni, às "atividades de natureza eminentemente intelectual") conformarem o material a ser utilizado por Gama durante as aulas particulares de Laura $^{17}$-, ela é, em larga medida, indicativa das correlações entre "o consumo privado e conspícuo" e a "construção de identidades sociais e sexuais", tal como as apreende Carvalho, ${ }^{18}$ ao mencionar que

[...] a continuidade de motivos ornamentais (arranjos florais, pássaros, ramagens) ou de matérias-primas e técnicas (plumas, sedas, rendas, estampas pintadas à mão) entre diversas categorias de objetos como leques, vidros de perfume, caixas de joias, chapéus, almofadas, trabalhos manuais nos mostram como são concretizadas nos objetos noções como harmonia, bom gosto, elegância, delicadeza, que encontramos abstratamente referidas na literatura como definidoras do ser feminino. ${ }^{19}$

Recorrendo às contribuições de Pierre Bourdieu, o arranjo cênico se nos afigura como ilustrativo do quanto

[...] a divisão entre os sexos parece estar 'na ordem das coisas', como se diz por vezes para falar do que é 
${ }^{20}$ Pierre BOURDIEU, 2002, p. 16 grifos meus.

${ }^{21}$ Gilda de Mello e SOUZA, 1987; BERNARDES, 1989, p. 6-7. De modo semelhante, Heleieth Saffiot (1976, p. 33) assinala que "a felicidade pessoal da mulher, tal como era então entendida, incluía necessariamente o casamento. Através dele é que se consolidava sua posição social e se garantia a sua estabilidade ou prosperidade econômica".

${ }^{22}$ SIMIONI, 2008, p. 57.

${ }^{23}$ Referindo-se a um período correspondente ao enfeixado no presente artigo, Simioni (2008, p. 64) lembra que "a maternidade tornara-se a principal, a mais nobre, a mais absorvente das tarefas femininas. Esse credo era compartilhado por ambos os sexos". Da mesma forma Eleutério $(2005$, p. 24) chama a atenção para o fato de que, "até há pouco tempo, a tendência da mulher era pensar que o foco de sua vida era o outro, a família de modo mais enfático, os filhos em especial".

${ }^{24}$ Júlia Lopes chegou a dedicar um volume às flores e ao seu cultivo. Trata-se de Jardim florido jardinagem, publicado em 1922. E tal era a recorrência com que 0 tema aparecia retratado em seus escritos, que não houve sequer gênero estilístico que não o tenha contemplado. Apenas para exemplificar, vale citar o romance Correio da roça (1913); a crônica "Floricultura", que integra o Livro das Noivas (1896), bem como o conto "A alma das flores", enfeixado no volume Ânsia eterna (1903) e dedicado a Lúcio de Mendonça. Neste último, o tema é retratado sob a ótica masculina de Sales, protagonista do enredo, que enxerga o cultivo de flores como fonte de realização pessoal. normal, natural, a ponto de ser inevitável: ela está presente, ao mesmo tempo, em estado objetivado nas coisas (na casa, por exemplo, cujas partes são todas 'sexuadas'), em todo o mundo social e, em estado incorporado, nos corpos e nos habitus dos agentes, funcionando como sistemas de esquemas de percepção, de pensamento e de ação. ${ }^{20}$

Outro aspecto a ser pontuado relaciona-se à ausência de qualquer menção, ao longo da trama, ao estado civil de Clotilde. Contudo, considerando-se que o casamento se afigurava, ao longo do Oitocentos, como via privilegiada de ascensão social e, o mais das vezes, também econômica da mulher, i.e., como o mais importante "vínculo de prestígio" a assegurar seu "movimento ascensional", ${ }^{21}$ não seria equivocado supor que a apresentação do cenário sugira se tratar de uma família burguesa tradicional, na qual as atribuições e afazeres da personagem em questão passariam ao largo da execução daquele rol de atividades remuneradas, com vistas a sanar urgências materiais e/ou a garantir a reprodução da existência social de sua família. Mais especificamente, Clotilde encarna a figura da "mãe prestimosa", para falar como Simioni, ${ }^{22}$ cuja preocupação primordial é não somente assegurar, mas também acompanhar de perto a educação da filha; para tanto, conta com o auxílio de Gama, que, como dito, desempenha o papel de preceptor de Laura. ${ }^{23}$

A ênfase do enredo recai sobre o elo e a cumplicidade existentes entre mãe e filha, bem como sobre dois temas que, em diferentes proporções, povoam a obra de Júlia Lopes, a saber, a educação feminina e a escravidão. A cada novo assunto, é a desenvoltura de Laura que rouba a cena. Merecem destaque o relato, à sua mãe, do sonho que tivera, ponto de partida da ação; sua consternação diante da boneca que desta ganhara como presente de aniversário; o interesse manifestado durante a aula particular com Gama; e, ao final, o modo como reage à inesperada "oferta" que seu professor lhe faz. Retomaremos cada uma dessas passagens na próxima seção.

A história se desenrola exatamente no dia em que Laura, personagem cujas principais características são a inteligência e a precocidade, completa nove anos de idade. A menção às flores e à exuberância do jardim, referências quase obrigatórias nos escritos de Júlia Lopes, permeiam o diálogo inaugural entre mãe e filha. ${ }^{24}$ Para se ter uma ideia, é de forma metafórica que a jovem, já em sua primeira aparição, evoca as flores para se referir ao seu aniversário:

Clotilde (encostada à janela, falando para Laura): Como vens florida, Laura!

Laura (da parte de fora, chegando à janela): — Uma verdadeira primavera, Mamá. 
Clotilde: - Entra, minha querida, quero beijar-te.

Laura (pondo a cesta de flores na janela): - Já vou... deixe-me primeiro cortar este botão! (E leva a flor à boca).

Clotilde: - Não a corte com os dentes!

Laura: Que remédio! Se não tenho aqui uma tesoura! E já me piquei!

Clotilde: - E para que desejar separar essa flor?

Laura: - Para pô-la nos seus cabelos.

Clotilde: - Deveras? Lisonjeira!... Sabes que dia é hoje? É a mim que cabe presentear. Anda, entra (com impaciência). Que tenho muito que te dizer. (À parte, como é galante!).

Laura (Entra sobraçando uma cesta de flores). Bravo! Viva! Viva Laura! Que faz hoje os seus nove anos e que está por isso toda contente. (Desce marchando e cantando, e atirando ao mesmo tempo flores para - ar, até à mesa da direita, onde fica a cesta, daí, corre para abraçar a mãe que tem descido até a poltrona da esquerda, lança-lhe os braços ao pescoço e beija-a em frenesi. ${ }^{25}$

${ }^{25}$ ALMEIDA, 1883, p. 3-4, grifos meus.

${ }^{26}$ CARVALHO, 2008, p. 88. Não por acaso, na crônica "Flores" (1906), Júlia Lopes inclui ao texto a seguinte nota introdutória: "Escrevo estas linhas pensando em minhas filhas. Elas me compreenderão quando forem mulheres e plantarem rosas para dar mel às abelhas e perfume a sua casa". ${ }^{27}$ CARVALHO, 2008, p. 89. Tal é o caso do conto "Esperando... (1903), em que Júlia Lopes descreve a comunhão entre a personagem e as flores da seguinte maneira: "A criada saiu. A dona da casa, moça, gentil, alegre, começou a dar uns retoques na mesa cantarolando na sua meia voz de soprano, um romance novo. Agora, punha ao lado da mesa o canário favorito sobre uma corbeille de flores naturais, daí a pouco temperava a salada, escolhendo com as pontas dos dedos, muito delicadamente, as folhinhas mais tenras [...] e, debruçando-se das janelas do jardim, puxava para dentro os galhos floridos das trepadeiras. Depois, relanceou por toda a sala os seus olhos vivos de burguesinha feliz".

${ }_{28}^{28}$ SOUZA, 1987, p. 100.
Ornamentos "fundamentais na atribuição de marcas femininas aos objetos", as flores, especialmente as naturais, sobretudo quando transpostas do jardim para o interior das salas, a exemplo do gesto espontâneo de Laura, recendem a "presença permanente da mulher" no ambiente doméstico ${ }^{26}$ e, o que é importante salientar, compõem emblematicamente aquele "universo de objetos com os quais se excitava a imaginação e a fantasia, território e arte das mulheres refinadas". ${ }^{27}$ Essa referência coaduna-se, pois, com o ambiente sofisticado em que a ação transcorre. Daí não nos parecer equivocado interpretar, nessa chave específica, o modo como a escritora nos apresenta à jovem personagem, cuja imagem chega mesmo a se confundir com a de uma "mimosa flor ainda em botão, que promete um desabrochar deslumbrante". 28

Aliás, na literatura da época, as etapas de maturação de uma flor não raro eram evocadas, com vistas a exprimir as diferentes fases da existência feminina, tal como nos sugere a formulação acima, de Gilda de Mello e Souza, se, ao longo da infância, a menina se via equiparada a um botão de rosa, seu desenvolvimento até a juventude (que é quando atinge a "flor da idade") seguia o ritmo compassado de um desabrochar. Além disso, as metáforas com flores, símbolo, a um só tempo, de beleza/exuberância e castidade/pureza/ candura, "eram utilizadas para descrever qualidades e 
29 CARVALHO 2008, p. 87-88. Carvalho recorre à seguinte passagem do romance Senhora, de José de Alencar, para exemplificar a homologia em questão: "A moça trajava verde. Ela tinha dessas audácias só permitidas às mulheres realmente belas, de afrontar a monotonia de uma cor. Seu lindo rosto, o colo harmonioso e os braços torneados desabrochavam dessa folhagem de seda, como lírios-d'-água rosados pelos rubores da manhã" (CARVALHO, 2008, p. 87). Aliás, o conto "In Extremis" (1903), de Júlia Lopes, é igualmente ilustrativo, na medida em que Laura, a protagonista, tem sua beleza narrada nos seguintes termos: "Eram para o outro [referindo-se ao personagem Bruno, suposto amante de Laura] a doçura do seu ramo de rosas, o mimo das suas rendas finas, o colorido brando da sua toilette primaveril".

${ }^{30}$ ALMEIDA, 1906, p. 47.

${ }^{31}$ À guisa de ilustração, Michel Foucault assinala que "para as moças existia, até meados do século XX, uma tradição que se chamava 'a viagem de núpcias': era um tema ancestral. A defloração da moça não poderia ocorrer em 'nenhum lugar' e, naquele momento, o trem, o hotel da viagem de núpcias eram bem esse lugar de nenhum lugar, essa heterotopia sem referências geográficas" (2009, p. 416, grifos meus. sentimentos femininos", chegando mesmo a promover uma espécie de fusão "entre corpo feminino e uma natureza frágil e delicada". ${ }^{29}$ Nas palavras de Júlia Lopes ${ }^{30}$, extraídas da crônica homônima, as flores

[...] simbolizam as nossas grandes alegrias, como as nossas grandes tristezas, imagens materializadas das maiores comoções da vida. Nas alegres visitas de boas festas e de aniversários, ou nas romarias para os cemitérios, as flores exprimem o júbilo ou a saudade, tão bem como a lágrima ou como sorriso.

Embora se afigure como uma flagrante digressão, não nos furtaremos a mencionar os contos "E os Cisnes?" e "O caso de Ruth", também de Júlia Lopes, ambos enfeixados no volume Ânsia Eterna (1903), já que são elucidativos do modo como as metáforas com flores integram o repertório da escritora. No primeiro texto, Serafina, personagem que vivia confinada em um "hospital de alienados" desde que perdera sua filha "afogada por causa de uns cisnes", exibia, como principal predicado, a brandura, traço marcante, a ponto de se dissipar por onde passava, tal qual "o perfume de um lírio". Por sua vez, em "O caso de Ruth", a protagonista do enredo, moça recatada, de "alma cândida" e "espírito virginal", "pura demais para viver na terra", é comparada tanto a "um lírio alvíssimo irrompido entre os florões grosseiros da alcatifa" quanto a uma "pétala de camélia não tocada". Aliás, não nos parece casual que o verbo "deflorar", quando tomado em seu sentido conotativo, designe justamente a perda da virgindade feminina. ${ }^{31}$

Ainda restrita aos motivos inspirados na natureza, Júlia Lopes dedica algumas linhas de "O Caminho do Bem" ao jardim, apresentando-o não simplesmente como o receptáculo natural das flores, espécie de tapete colorido a céu aberto, mas como um espaço de "entrosamento" e "encantamento", no qual crianças e plantas estabelecem uma "feliz comunhão". Tal ideia, posteriormente retomada na crônica "Floricultura" (1914), é expandida, a ela se dissolvendo certas referências autobiográficas:

O jardim é, sobretudo, útil onde houver crianças. Esses pequenos seres, tão delicados e tão puros, vivem adoravelmente em companhia dos jasmins e dos lírios! Eu passava horas inteiras, em pequena, moendo no jardim às maravilhas, fazendo falar as flores, dandoIhes nomes, humanizando-as, (perversidade inconsciente da infância!) e, depois d'esse tempo, quantas crianças não tenho eu visto a fazer o mesmo, exatamente o mesmo!

As mães sentem-se tranquilas, porque ali as suas filhinhas podem rolar à vontade pela areia branca que não enxovalha as roupas, ou pela grama macia,

1106 Estudos Feministas, Florianópolis, 21 (3): 1099-1119, setembro-dezembro/2013 
${ }^{32}$ ALMEIDA, 1914, p. 142-143. No texto "Outros espaços", fruto de uma conferência proferida em 1967, Foucault lembra que "o jardim é, desde a mais longínqua Antiguidade, uma espécie de heterotopia feliz e universalizante" (2009, p. 418).
${ }^{33}$ ALMEIDA, 1883, p. 5. Atenta à chegada do professor, Laura imediatamente associa a última aula que com ele tivera a seu sonho, ao se lembrar que o assunto então abordado era a História da África. As referências ao continente, às suas extensas florestas e, em especial, à escravidão, tema este que, como dito, reaparecerá ao final do drama, entremeiam a fala da personagem, sob a forma de estereótipos e lugares-comuns: Laura (Recordando-se): - Ah! Agora me lembro... Foi a lição de ontem que me fez sonhar! Foram aqueles desenhos; foram aquelas florestas; foram aquelas gentes d'África! De que ele me falou! Foi!... (pausa) Oh! Minha mãe, então tudo pode ser verdade! Não dizem que arrancavam as crianças de suas terras, e que as levavam roubadas para longe de seus pais?! Ah! Era horrível! Era horrível!... quando o tempo está seco. Depois, os seus olhos ingênuos e curiosos terão em frente um espetáculo delicadíssimo, alegre, perfumado, são.

Ao recolherem-se para o lunch, para qualquer das refeições, para o banho ou para o estudo, virão impregnadas do aroma das ervas, trarão nas faces a cor purpurina dos aromas de Alexandria, e no olhar como que um reflexo do céu, iluminado e brilhante! ${ }^{32}$

Em meio às manifestações de deslumbramento para com as flores e jardim, Laura revela à mãe certa consternação e atribui tal sentimento ao sonho que tivera, responsável por tirá-la da cama antes do horário de costume. Essa referência, que nada tem de fortuita, antecipa um tema que, ao final do entrecho, se torna fulcral. Trata-se da escravidão, abordada, em um primeiro momento, sob a ótica distorcida de Laura, contaminada por uma atmosfera onírica, mas retomada, ao final da ação, não apenas como o antípoda da educação, mas como pano de fundo da "mensagem" que a peça tenciona transmitir, cujo título "O Caminho do Bem" é a sua mais perfeita expressão. Isso posto, o fragmento a seguir reproduz o modo como a aniversariante relata a sua mãe o conteúdo de seu sonho:

Laura: - Sonhei que estava perdida numa floresta. Fazia um frio... um frio! Eu trazia um vestido muito pobre muito rasgado e muito curto. Eu tinha as pernas nuas e os pés descalços. Nunca vi o sol tão triste como esta noite em sonhos!... todo cercado de nuvens grandes; negras! E eu sempre a caminhar [...], gelada, a tremer! Eu não era eu; minha mãe não era a minha mãe! Eu ia sozinha, olhando para as folhas das árvores; folhas que iam como eu, abandonadas, impelidas pelo vento, ao destino! (com lágrimas na voz) Ah! Não conto o resto...

[...]

- De repente (levantando-se), saíram de uma gruta dois homens muito grandes, dos... medonhos! Todos cheios de armas que avançando para mim, disseramme com uma voz muito grossa: estás presa e você ser escrava! ${ }^{33}$

Clotilde, que chega a interromper o bordado para dedicar integral atenção à narração da filha, aguarda seu desfecho e, então, intercede. Os comentários tecidos pela mãe, transcritos a seguir, não somente pontuam o desalinho existente entre, de um lado, a "clareza de inteligência" demonstrada pela filha e, de outro, sua idade, mas também põem em tela os possíveis efeitos nocivos que tamanha capacidade inventiva pode ter sobre sua saúde, dada a fragilidade de seu corpo de menina. 
${ }^{34}$ ALMEIDA, 1883, p. 9.

\begin{abstract}
${ }^{35}$ SIMIONI, 2008, p. 60.
36 Bonnie G. SMITH, 2003, p. 387 Na crônica "A Mulher Brasileira", incluída no volume Livro das Donas e Donzelas (1906), Júlia Lopes faz menção à "antipatia do homem pela mulher intelectual, que ele agride e ridiculariza" (ALMEIDA, 1906, p. 9).

${ }^{37}$ SIMIONI, 2008, p. 61
\end{abstract}

${ }^{38}$ SIMIONI, 2008, p. 61. Saffioti lembra o quão perniciosas eram essas explicações, ao atribuírem "[ao] desuso do cérebro a que a sociedade condenara a mulher, negando-se a instruí-la, [a responsabilidade] pela menor evolução verificada das capacidades mentais femininas" (SAFFIOTI, 1976, p. 206) ${ }^{39}$ Marina MALUF e Maria Lúcia MOTT, 2006, p. 373-374.
Clotilde: - Laura tem imaginação demais para a sua idade, uma clareza de inteligência, uma nitidez de idéias, tais que parece-me impossível que se aninhem num cérebro de criança!... depois, o corpo é fraco e as arrojas daquela fantasia, como que lhe prejudicam a saúde. ${ }^{34}$

Tal posicionamento faz coro àquela miríade de discursos "pregados pela lgreja, ensinados por médicos e juristas, legitimados pelo Estado e divulgados pela imprensa", amplamente difundidos ao longo do século XIX e início do XX, que tencionavam alertar a sociedade acerca dos "perigos que rondavam a excessiva intelectualização das mulheres", ${ }^{35}$ entre os quais estariam o arrefecimento dos traços definidores de sua feminilidade e, desta feita, o comprometimento mesmo de certa "identidade de gênero". ${ }^{36}$

Por exemplo, aos "saberes" médicos - espécie de "visão sociologizante da teoria darwiniana" ${ }^{37}$-, munidos de toda a autoridade que a "chancela científica" seria capaz de conferir, coube explicar o dimorfismo sexual, ou melhor, seus desdobramentos em atributos e características anatômicas e fisiológicas que distinguem os dois sexos, segundo os quais "a natureza feminina determinava um caráter frágil, uma propensão para as doenças". ${ }^{38}$ Com efeito, tais apreensões fundamentavam aquele conjunto de "prescrições do dever ser" que não apenas forjou "a imagem da mãe-esposa-dona de casa como a principal e mais importante função da mulher", como converteu tais comportamentos em "rígidos papéis sociais". ${ }^{39}$

À guisa de ilustração, similar apreciação chega a ser mencionada na palestra "A Mulher e a Arte", proferida por Júlia Lopes em 1918, no Rio Grande do Sul. Em sua preleção, a escritora tanto reconhece que "para uma mulher conseguir em arte metade do que consegue um homem, de igual talento e de igual vontade, tem que despender o décuplo do esforço", quanto vincula tal constatação "[às] contingências físicas do seu organismo, [ao] sentimento perturbador da maternidade, cujos instintos se anunciam nela desde criança, e, mais do que tudo, [à] sua falta de instrução e de liberdade".

Voltando à trama, outro aspecto relevante diz respeito ao desalento de Laura ante a notícia de que sua mãe havia Ihe comprado uma boneca, em comemoração ao seu aniversário. Nas palavras da jovem, "uma boneca" não passava de "uma frivolidade". Intercedendo em favor da patroa (Clotilde), esse é o trecho em que a participação da criada Zina se faz mais efetiva, não apenas ao enaltecer a beleza da boneca, cujos olhos azuis reluzem, como ao estabelecer uma previsível comparação entre o brinquedo e a jovem, segundo a qual "a boneca é rica, como a sua mãezinha". A tentativa de convencimento é arrostada pelo juízo crítico de Laura, que dá o tom de sua fala:

1108 Estudos Feministas, Florianópolis, 21 (3): 1099-1119, setembro-dezembro/2013 
${ }^{40}$ ALMEIDA, 1883, p. 11-12.

${ }^{41}$ Pierre BOURDIEU, 2009, p. 138

${ }^{42}$ CARVALHO, 2008, p. 23

${ }^{43}$ Maria Odila Leite da Silva DIAS 1995 , p. 51-52.
Criada (Tomando a boneca das mãos de Laura e examinando-a): Oh! Mas é muito bonita! Que lindos olhos azuis que ela tem!

Laura: - De vidro... olhos que não vêem, que não têm expressão... que não remexem cá dentro do coração!

Criada: - E a boca?! Como é pequenina!

Laura: - Sim, mas não fala, não se entreabre num sorriso!... não me importava que fosse bem rasgada, contanto que fosse verdadeira, que risse, que falasse e que me beijasse!

$[\ldots]$

Criada: - [...] Ela [a boneca] tem sapatinhos cor-derosa e meias de fio de Escócia! Bem se vê que é rica, como a sua mãezinha! 40

As intervenções da criada põem em descoberto a barreira simbólica existente entre ambas, a anunciar, para além das diferenças econômicas e culturais, ${ }^{41}$ aquelas de natureza fenotípica. E não parece haver casualidade no fato de as menções à personagem Zina, ao longo do documento original - especialmente naqueles espaços destinados às marcações das falas das personagens -, reduzirem-se ao emprego daquele vocábulo genérico que define a sua profissão, a saber, do substantivo "criada". A invisibilidade de Zina ilustra muito bem o fato de que "a parcela pobre da população só figura no contexto da casa burguesa a seu serviço, ou seja, como empregados", ${ }^{42}$ ou, ainda, o fato de

[...] as mulheres pobres no processo de urbanização de São Paulo, socialmente desqualificadas, pertence[re]m ao domínio dos espaços e papéis informais, improvisados, sintomas de necessidades novas e de mudanças estruturais [...] Papéis informais, por sua própria natureza, não são oficialmente reconhecidos nem socialmente muito valorizados, embora sejam importantes no processo concreto da vida cotidiana. ${ }^{43}$

Sob esse aspecto, a crônica "Por quê?" (1906), de Júlia Lopes, não apenas repisa "em cheio" referida temática, como vai além: "arranca" a criadagem da invisibilidade, para transformá-la em alvo de acerbadas críticas. Sob o olhar sentencioso da protagonista - investida que estava da autoridade de "patroa" -, a "gente de serviço" é retratada, sem volteios, como fonte de tormento e amolação. Em linhas gerais, a crônica explora as tensões que presidem a relação entre "servir e ser servida", a partir de um ponto de vista em nada isento, explicitamente comprometido com a vitimização da "dona da casa" (paradoxalmente autoconvertida em 
${ }^{44}$ ALMEIDA, 1906, p. 21, grifos meus.

${ }^{45} \mathrm{~A}$ propósito da infância como categoria social geracional, cf. Bárbara E. PEREIRA e Maria Letícia B. P. NASCIMENTO (2011).

${ }^{46}$ Philippe ARIÈS, 1978, p. 48.
${ }^{47}$ A menção a Hamlet acaba por contrapor, em alguma medida, as personagens à figura "ideal" da mulher burguesa. Nos termos de Goblot, "une honnête femme peut lire quelques livres; pas trop, et des livres inoffensifs, des livres de tout repos, approuvés par son mari et surtout par son directeur. Lidée que la bourgeoisie s'est faite de la moralité a rendu impossible l'éducation littéraire et artistique de la femme" (GOBLOT, 1930, p. 73). "mártir", por conseguir "aturar" a indolência e a má vontade dos empregados):

A dona de casa no Brasil é a mártir mais digna de comiseração entre todas as citadas pela história. Viver embaixo das mesmas telhas com uma inimiga que faz tudo o que pode para atormentar as nossas horas, pagar-lhe os serviços e ainda fazê-los de parceria, assumindo a responsabilidade dos maus jantares que ela faz e da maneira desleixada por que arrasta a vassoura pela casa; ordenar e ser desobedecida; pedir e obter más respostas; falar com doçura e ouvir resmungar com aspereza; advertir com justiça e ouvir responder com agressão e brutalidade; recomendar limpeza, economia, ordem e calma, e ver só desperdícios, porcaria, desordem e violência, confesso que é coisa de fazer abalar em vibrações dolorosas os nervos os mais modestos, mais tranquilos e mais saudavelmente pacatos do mundo! ${ }^{44}$

Para além dos assuntos até então pontuados, e sem descurar da abordagem dos desníveis entre as classes sociais, o texto teatral lança luz, tal como ficou evidente, sobre a perspectiva "geracional", na qual a infância ocupa o primeiro plano. ${ }^{45}$ Mas, se o protagonismo de Laura mantém certo ponto de contato com as constatações de Philippe Ariès, para quem a infância se exibe como fase privilegiada do século $\mathrm{XIX}, 46$ tal centralidade vem acompanhada não exatamente daqueles qualificativos correntemente atribuídos a tal etapa da vida, a saber, a ingenuidade, a passividade, a inocência: o que se depreende da trama é, como dito, o "grau" de maturidade e a precocidade manifestados pela personagem. Exemplo notório, além do episódio em que recusa a boneca, é o trecho em que Laura se mostra não apenas ciente das expectativas que sua mãe, a personificação do "mundo adulto", Ihe dirige - visível ao antecipar, com ironia, o teor da conversa que travariam -, mas ao buscar em Hamlet inspiração para sua fala, referência esta imediatamente reconhecida por Clotilde: ${ }^{47}$

Laura: - Perdoe-me e... fale... (pondo-lhe nos cabelos o botão [de rosa], que antes guardara no peito) fale... que eu sou toda ouvidos; e que ouvidos! De curiosa!... apesar de já desconfiar do que a minha adorável mãezinha me vai dizer... vai dar-me (tragicamente) conselhos... conselhos... e conselhos. Que pena faltarme aqui a capa do homem do teatro, para dizer como ele: palavras, palavras e... palavras.

Clotilde: - Escusas de citar Hamlet. Reconheci-lhe o tom.

Como já salientado, é também no trato com Gama que Laura põe à prova seus conhecimentos, bem como se

1110 Estudos Feministas, Florianópolis, 21 (3): 1099-1119, setembro-dezembro/2013 
${ }^{48}$ ALMEIDA, 1883, p. 13-14.

${ }^{49} \mathrm{Cf}$. SAFFIOTI, 1976; Ivan MANOEL, 1996; Nádia Battella GOTLIB, 2003.

\footnotetext{
${ }^{50}$ Nota-se, portanto, que "o aspecto geracional interage com outros fatores de estratificação social, como gênero, etnia e classe econômica" (PEREIRA e NASCIMENTO, 2011 , p. 6).
}

${ }^{51}$ ALMEIDA, 1883, p. 25. regozija ante as deferências que lhe são dirigidas, a cada lição cumprida. O professor, ciente da "precocidade" da aluna, assim como de sua preferência por aquilo que é "verdadeiro" (justificativa esta que a jovem utilizou para fundamentar seu argumento acerca do desinteresse pela boneca), propõe presenteá-la com um papagaio, "que reponde com grande palavreado quando a gente lhe diz: dá cá o pé, meu loiro". Porém Gama condiciona tal oferta ao desempenho de Laura na "lição" de Geografia, que estava prestes a se iniciar. Mais uma vez, a personagem demonstra sua sagacidade:

Gama: - Boneca, não, porque não fala... um papagaio que tenho lá em casa e que reponde com grande palavreado quando a gente lhe diz: dá cá o pé, meu loiro? Que acha? Não a seduz o prêmio?

Laura (como ofendida, irônica): Oh! Muito! E hei de pôlo aqui perto da mesa... Ele há de ouvir as nossas lições e há de repetir-mas depois... verá como vão ficar perfeitos os meus estudos! ${ }^{48}$

Durante a aula, sobre coordenadas geográficas, a jovem responde a todas as questões formuladas por Gama e gaba-se também por saber, "perfeitamente, o nome de todas as terras, de todos os rios, e de todas as montanhas...". Em revelador compasso com o contexto em que fora gestada, 0 entrecho tematiza a educação feminina destinada às moças pertencentes às famílias abastadas do Oitocentos como um processo, em sua quase totalidade, informal, ficando sua transmissão a cargo da figura do preceptor. ${ }^{49}$

Ao final da trama, entra em cena uma segunda criança. Trata-se de Gustavo, alguns anos mais jovem do que Laura, filho de uma escrava do Norte, mas dela apartado durante uma transação comercial, na qual sua mãe fora cedida com vistas à quitação de uma dívida que o senhor de escravos, seu proprietário, havia contraído. Com o falecimento deste, e por decisão judicial, Gama foi designado seu tutor provisório. Se, no caso de Laura, os privilégios de uma educação esmerada, cuja transmissão se realizava por meio da figura do preceptor, estimulavam seu "espírito inquieto", sua "precocidade", no caso de Gustavo, sua indigência social exemplifica emblematicamente as faces vis de uma infância que lhe fora torpemente usurpada..$^{50}$

Gama: - Este último senhor morreu há oito dias, como era viúvo e não tinha filhos (mostrando Gustavo) ele ficou sozinho. O juiz nomeou-me seu curador, dizendoIhe que me servisse e obedecesse. Quando o vi e lhe ouvi contar a sua vida, perguntei-Ihe se tinha vontade de estudar, de saber, de fazer-se homem como os brancos, e ele ficou tão contente, tão contente $[. . .]^{51}$ 
${ }^{52}$ ALMEIDA, 1883, p. 19-20, grifos meus.

${ }^{53}$ BERNARDES, 1989,p. 32.

${ }^{54}$ MALUF e MOTT, 2006, p. 374

Como assinalam Maluf e Mott, "baseado na crença de uma natureza feminina, que dotaria a muIher biologicamente para desempenhar as funções da esfera da vida privada, o discurso é bastante conhecido: o lugar da mulher é o lar, e sua função consiste em casar, gerar filhos para a pátria e plasmar - caráter dos cidadãos de amanhã. Dentro desta ótica não existiria realização possível para as mulheres fora do lar; nem para os homens dentro de uma casa, já que a eles pertenceria a rua e 0 mundo do trabalho" (2006, p.374)

${ }^{55}$ Leonora DE LUCA, 1999, p. 291.

${ }^{56}$ BERNARDES, 1989, p. XV.
Sem intenção de assumir definitivamente a guarda de Gustavo, o professor tenciona transferir tal responsabilidade à Clotilde, que aceita receber o petiz em sua residência. É então que, coincidindo com o término da aula particular, a campainha soa, anunciando-se a chegada de Gustavo, apresentado à personagem nos seguintes termos:

Gama (para Clotilde, apresentando-Ihe Gustavo): É este o ingênuo de que falei a V. Exa. O réprobo da sociedade de hoje, que embora livre amanhã, terá sempre gravado na fronte o ignominioso selo do berço em que nasceu, se não lh'o arrancarem as mãos da caridade, mãos que devem mostrar-lhe o caminho da honra e do dever, elevando-lhe o espírito amesquinhado pela escravidão ao nível do gladiador na arena da liberdade, e dando ao país, em vez de um ente que é a sua vergonha, um homem que é a sua utilidade!

Clotilde: — E posso eu?!...

Gama: - A mulher pode tudo na educação dos povos.

Clotilde (concentrando o pensamento, e depois com decisão): Bem! Trabalharemos eu e minha filha, para tornar o homem digno da sociedade futura, o que é desprezado pela sociedade de hoje.

Gama: - Entrego-o a V. Exa., porque sei qual é a sua elevação de idéias e de sentimentos. 52

Tal como propõe o trecho acima, Clotilde é descrita como a representação da "mulher educada" do Oitocentos, "esteio moral da família, eixo vital da sociedade" 53 imbuída da nobre missão de "plasmar o caráter dos cidadãos de amanhã". ${ }^{54}$ Aliás, no texto teatral, a educação chega mesmo a se converter em "ato de nobreza e benevolência", capaz de elevar, ou, ao menos, "humanizar" aqueles "espíritos amesquinhados pela escravidão". A esse respeito, Leonora de Luca, atenta ao repertório temático mobilizado por Júlia Lopes ao longo de seu percurso artístico, identifica como eixos característicos de seus textos de estreia a preocupação com a "condição feminina", que se fazia acompanhar "de denúncias acerca do caráter deletério do sistema escravocrata: não raro a problemática feminina aparece entrelaçada com ideias abolicionistas". ${ }^{55}$

Nessa mesma linha de juízo, o período acima transcrito também dialoga com as considerações de Bernardes, para quem a "inferiorização e marginalização da mulher, dentro e fora do lar, não pareciam marcar irremediavelmente sua posição nas famílias urbanas abastadas [...] da segunda metade do século XIX". ${ }^{56}$ Dito de outro modo, as personagens

1112 Estudos Feministas, Florianópolis, 21 (3): 1099-1119, setembro-dezembro/2013 
57 BERNARDES, 1989, p. 6.

${ }^{58}$ BERNARDES, 1989, p. 1.

${ }^{59}$ ALMEIDA, 1914, p. 200.

${ }^{60}$ ALMEIDA, 1914, p. 201.

${ }^{61}$ ALMEIDA, 1883, p. 21-22. centrais do drama distanciam-se, em alguma medida, daquele "molde em que habitualmente [as mulheres do período] eram consideradas", ${ }^{57}$ ainda que não o transgridam propriamente, uma vez que a educação, na trama, muito mais se aproxima da ideia de "cultivo do espírito", com vistas à "dignificação da família, da nação e do mundo". ${ }^{58}$ Aliás, Júlia Lopes repisa esta mesma temática na crônica "Educação", incluída no Livro das Noivas (1914), ao definir "o ensino dos filhos" como um "encargo que nenhuma mãe deveria declinar de si": ${ }^{59}$

Nenhum mestre pode ser mais insinuante, mais querido, mais doce, mais persuasivo, do que a mãe! E é principalmente essa missão que deve induzir todas as moças a ler e a estudar com atenção. Aprender para ensinar, com inteligência, alegremente, maternalmente! ! $^{60}$

Por seu turno, e tal como uma mercadoria, um "presente", Gama oferta Gustavo à Clotilde e à Laura. Não se tratava, pois, do papagaio, como chegou a supor a jovem quando ouviu Gama afirmar, ao som da campainha, que o "presente" havia chegado, mas sim do "réprobo da sociedade" de então, "que traz gravado na fronte o ignominioso selo do berço em que nasceu".

Clotilde: - Escuta, é o presente prometido, que ele te quer ofertar...

Laura: — O quê?! O papagaio?! (rindo, aproximandose vê Gustavo, fica admirada).

Gama: - É um presente muito sério.

Laura (olhando atenta para todos): Muito sério! (imitando o tom de Gama) Mas que quer dizer tudo isto?... Que mistérios são estes!?! Onde está o presente?! Foi este rapaz que o trouxe? (apontando Gustavo), onde o botaste, ó...?

Clotilde: O presente, filha, é para o teu coração. Desteme hoje uma lição de que jamais me esquecerei.. Ofertei-te uma boneca, e disseste-me que era uma frivolidade! ${ }^{61}$

Percebida por Laura com desconcertante estranhamento (sentimento este não muito distinto do manifestado por Clotilde), a presença de Gustavo é incômoda, uma espécie de afronta à "boa sociedade", na medida em que exprime o escancaramento de desigualdades sociais, profundas $e$ incontornáveis. Exultante e com ar de superioridade, a jovem personagem repisa tal hiato ao examiná-lo e perquiri-lo com veemência. Contudo, as breves respostas que obtém, titubeantes, acabam por constrangê-la. 
Laura: —Então, Gustavo, conta-me a história. (silêncio) Estás mudo?!... Não ouves!? (com autoridade) Ordenote! Fala!

Gustavo: - Curva a cabeça e chora.

[...]

Laura (interrompendo-a): Já sei! (puxa uma cadeira para o centro da cena, senta-se com ares de juiz, de cabeça levantada, com voz cheia) Sou o juiz! Réu... responda, onde nasceste?

Gustavo (humilde): Não sei...

Laura: - Oh! Pois sua mãe não te disse?

Gustavo: - Não senhora.

Laura: - Quem é tua mãe?

Gustavo: - Uma escrava.

Laura: - Mas onde está?

Gustavo: - Não sei.

Laura (pensativa): Não sei! (levanta-se, chega-se para a mãe) Não sabe! (para Clotilde). Pois é possível que ele não saiba da mãe... ele, que é tão pequeno! ${ }^{62}$

Na esteira dessas considerações, cabe ainda destacar a acurada terminologia empregada por Júlia Lopes para se referir a Gustavo. Trata-se do vocábulo "ingênuo", tomado, ao que tudo indica, intencionalmente, em sua dupla acepção: como sinônimo de inocência (um contraponto à "maturidade" de Laura) e, o que é mais importante considerar, como uma referência à "estirpe" à qual a criança pertence. Isso porque tal termo, em seu sentido menos corrente, mas aqui não menos importante, é uma espécie de "localizador social", a definir/nomear os descendentes diretos de escravos (mais propriamente, os escravos recém-libertos). Ao apresentar Gustavo como ingênuo, a dramaturga parecia menos interessada em destacar seus predicados individuais do que em "categorizá-lo" socialmente, e tal jogo semântico é indicativo de que a alusão à ingenuidade propriamente dita é portadora da denúncia do elo íntimo que a sociedade mantinha com a escravidão.

Se a figura de Gustavo alude, por um lado, às agruras subjacentes à ordem senhorial, aos séculos de aviltamento a que os negros foram submetidos em nossa sociedade, aos corolários desta prática parasitária, tais como a falta de perspectiva e a consequente marginalização social, por outro, sua presença pueril e "ingênua" sinaliza, em alguma medida, a possibilidade de um diferente porvir, muito embora a chave transformadora esteja contida, no caso em

1114 Estudos Feministas, Florianópolis, 21 (3): 1099-1119, setembro-dezembro/2013 
${ }^{63}$ ALMEIDA, 1883, p. 25-7.

${ }^{64}$ SAFFIOTI, 1969, p. 223.

${ }^{65}$ NEEDELL, 1993, p. 85. questão, nas "mãos da caridade", i.e. veja-se reduzida a iniciativas voluntariosas e assistencialistas de senhoras "piedosas e de boa intenção".

Clotilde: — Dá-te teu mestre o encargo de introduzires na sociedade uma criatura expulsa dela, de nivelares pelo teu um coração, de ensinares as veredas floridas da virtude, a quem nasceu rodeado de espinhos! Ensina-o, eleva-o, que te elevarás!

[...]

Laura - Sim! Querem que seja eu quem ensine, quem reparta com um filho da desgraça os bens que Deus me deu! E como eu Ihes agradeço! (abraçando a mãe e Gama) É minha mãe!... É meu mestre!... Como os anjos do meu sonho mostram-me o caminho do Céu!!... (Gustavo beija-Ihe ajoelhado a mão, Gama comovido enxuga os olhos, Clotilde contempla o quadro afagando Laura)

Cai o pano. ${ }^{63}$

Grosso modo, na trama, a educação não se afigura propriamente como um instrumento para a emancipação feminina, uma vez que, sob a "insuspeita" fachada da "preeminência moral e social da mulher", se oculta sua "heteronomia econômica e política". ${ }^{64}$ Quanto a isso, a crônica "A Mulher Brasileira" (1906), anteriormente citada, é sobremaneira esclarecedora:

A verdade, que deve aparecer aqui, é que nos acontecimentos culminantes da nossa história, aqueles que nos fatos da nacionalidade brasileira iniciam períodos de renovação e de progresso - $a$ independência, a abolição, a república - a intervenção da mulher, direta ou indiretamente considerada, quando não foi nula foi hostil.

Em outros termos, a educação de Laura adquire contornos, por assim dizer, moralizantes: fazer com que fosse investida de qualificativos capazes não apenas de "melhor servirem como instrumento de civilização do mundo íntimo da elite", 65 mas também de "livrarem", tanto quanto possível, aquelas "almas açoitadas pela escravidão" de sua ignominiosa "herança".

\section{Considerações finais}

As linhas de leitura encaminhadas neste artigo permitem-nos considerar que o repertório temático que Júlia Lopes mobilizou para a composição do enredo e da criação das personagens muito nos informa a respeito da sociedade em que viveu, em especial no concernente às relações de gênero. Não nos deixa mentir a personagem Clotilde, cuja presen- 
${ }^{66}$ SIMIONI, 2004, p. 95

${ }^{67}$ CARVAlHO, 2008, p. 20-22.

\footnotetext{
${ }^{69}$ Não seria equivocado afirmar que o desfecho da peça tematiza não somente o verniz farisaico de uma sociedade que assiste, da sala de estar, ao desmantelamento da ordem senhorial e escravista como faz coro à afirmação de Florestan Fernandes (1972, p. 40), para quem "o padrão brasileiro de relação racial foi construído para uma sociedade escravista, ou seja, para manter o 'negro' sob a sujeição do 'branco'”.
}

ça ilustra, de forma emblemática, o quanto às mulheres pertencentes às famílias abonadas estava resguardada a posição de "adorno doméstico, cuja única função socialmente relevante era a de gerir o lar e educar os filhos". ${ }^{66}$

Além disso, a descrição do cenário (relativa aos objetos e mobiliários que o guarnecem) revelou-se um potente recurso empregado por Júlia Lopes, capaz de facultar ao leitor o reconhecimento prévio do "território físico e social" em que a ação transcorreria. Ao descortinar tais dimensões cênicas, a dramaturga possibilitou-nos vislumbrar não apenas as "formas materiais da [posição] social" das personagens, mas também reconhecer que certos aspectos das "relações de gênero" poderiam ser compreendidos à luz "dos padrões de organização material da moradia". ${ }^{67}$

Por exemplo, considerando-se a elegante sala de estudos da residência de Clotilde, percebe-se que a disposição do bordado sugere tanto o seu distanciamento (também em termos simbólicos) em relação aos livros, ao tinteiro e aos papéis, fazendo lembrar a vetusta antinomia, como já apontado, entre "coisas do espírito" e "trabalhos manuais", quanto, e mais especificamente, insinua que "o uso de objetos na casa" se dá de forma "sexuada" (até mesmo se considerarmos que os itens que aludem ao "mundo intelectual" venham a compor o arsenal escolar utilizado nas aulas particulares de Laura, uma vez que, no entrecho, a educação feminina tem em vista, essencialmente, o polimento sociocultural da personagem). Outro ponto digno de nota é a menção ao ato de coser: ao ser apresentado como passatempo de Clotilde, tal referência acaba por repisar a relação entre "gênero" e afazeres tidos como "naturalmente femininos". 68

Por fim, cabe destacar que o drama, ao iluminar certos aspectos do "estilo de vida" da família burguesa de fins do século XIX, deixa entrever, para além do tipo de educação destinada às moças bem-nascidas, o modo como a escravidão fazia parte da vida ordinária das mulheres pertencentes aos círculos abonados: como um problema que só era concretamente percebido quando batia à suntuosa porta de suas residências (no caso em questão, literalmente). ${ }^{69}$ À escravidão, com seus estigmas (carreados pelo "ingênuo" Gustavo), corresponde a educação, apresentada como o instrumento, par excellence, por meio do qual seria possível "recuperar" as almas aviltadas e desumanizadas pela ordem senhorial, "conduzindo-as" em direção ao "caminho do bem".

\section{Referências}

ARIÈS, Philippe. História social da criança e da família. Rio de Janeiro: Editora Guanabara, 1981. 
BERNARDES, Maria Thereza Caiuby Crescenti. Mulheres de ontem? Rio de Janeiro - século XIX. São Paulo: T. A. Queiroz, 1989.

BOURDIEU, Pierre. A dominação masculina. Rio de Janeiro: Bertrand Brasil, 2002. 2009.

O poder simbólico. Rio de Janeiro: Bertrand Brasil,

BROCA, Brito. "A mulher na literatura brasileira." In: Românticos, pré-românticos, ultra-românticos: vida literária e romantismo brasileiro. São Paulo: Polis/INL/MEC, 1979. (v. 1 das Obras reunidas).

CARVALHO, Vânia Carneiro de. Gênero e artefato. O sistema doméstico na perspectiva da cultura material - São Paulo, 1870-1920. São Paulo: EDUSP/FAPESP, 2008.

"Cultura material, espaço doméstico e musealização." Varia hist., Belo Horizonte, v. 27, n. 46, dez. 2011.

DE LUCA, Eleonora. "O 'feminismo possível' de Júlia Lopes de Almeida." Cadernos Pagu, n. 12, p. 275-299, 1999.

DIAS, Maria Odila Leite da Silva. Quotidiano e poder em São Paulo no século XIX. São Paulo: Brasiliense, 1995.

ELEUTÉRIO, Maria de Lourdes. Vidas de romance: as mulheres e o exercício de ler e escrever no entresséculos (18901930). Rio de Janeiro: Topbooks, 2005.

FERNANDES, Florestan. O negro no mundo dos brancos. São Paulo: Difel, 1972.

FOUCAULT, Michel. "Outros espaços." In: . Estética: literatura e pintura, música e cinema. Rio de Janeiro: Forense Universitária, 2009. (Coleção Ditos \& Escritos III).

GOBLOT, Edmond. La barrière et le niveau. Étude sociologique sur la bourgeoisie. Paris: Félix Alcan. Bibliothèque de philosophie contemporaine, 1930.

GOTLIB, Nádia Battella. "A literatura feita por mulheres no Brasil." In: BRANDÃO, Izabel; MUZART, Zahidé. Refazendo nós: ensaios sobre mulher e literatura. Florianópolis: Editora Mulheres, 2003.

KINCHIN, Juliet. "Interiors: Nineteenth-Century Essays on the Madculine and Feminine Room". In: KIRKHAM, Pat (Ed.). The gendered object. Manchester: Manchester University Press, 1996.

MALUF, Marina; MOTT, Maria Lúcia. "Recônditos do mundo feminino." In: NOVAIS, Fernando A. (Coord.); SEVCENKO, Nicolau (Org.). História da vida privada no Brasil República: da Belle Époque à Era do Rádio. São Paulo: Companhia das Letras, 2006.

MANOEL, Ivan. Igreja e educação feminina (1959-1919): uma face do conservadorismo. São Paulo: Editora da Universidade Estadual Paulista, 1996. 
MIGUEL-PEREIRA, Lúcia. História da literatura brasileira: prosa de ficção (de 1870 a 1920). Belo Horizonte: Itatiaia; São Paulo: Editora da Universidade de São Paulo, 1988.

MOREIRA, Nadilza Martins de Barros. A condição feminina revisitada: Júlia Lopes de Almeida e Kate Chopin. João Pessoa: Editora Universitária/UFPB, 2003.

NEEDELL, Jeffrey. Belle époque tropical: sociedade, cultura de elite no Rio de Janeiro na virada do século. São Paulo: Companhia das Letras, 1993.

PEREIRA, Bárbara E.; NASCIMENTO, Maria Letícia B. P. "De objetos a sujeitos de pesquisa: contribuições da Sociologia da Infância ao desenvolvimento de uma etnografia da educação de crianças de populações tradicionais." Educação: Teoria e Pesquisa, v. 21, n. 36, jan./jun. 2011.

PERROT, Michelle. As mulheres ou os silêncios da história. Bauru, SP: EDUSC, 2005.

SAFFIOTI, Heleieth lara Bongiovani. A mulher na sociedade de classes: mito e realidade. Petrópolis: Vozes, 1976.

SALOMONI, Rosane S. D. A escritora/os críticos/a escritura: o lugar de Júlia Lopes de Almeida na ficção brasileira. 2005. Tese (Doutorado em Letras) - Programa de PósGraduação em Letras, Universidade Federal do Rio Grande do Sul, Porto Alegre.

SIMIONI, Ana Paula Cavalcanti. Profissão Artista: pintoras e escultoras brasileiras entre 1884 e 1922. Tese (Doutorado em Sociologia) - Faculdade de Filosofia, Letras e Ciências Humanas, Universidade de São Paulo, USP. São Paulo, 2004. Profissão artista: pintoras e escultoras acadêmicas brasileiras. São Paulo: EDUSP/FAPESP, 2008. "Bordado e transgressão: questões de gênero na arte de Rosana Paulino e Rosana Palazyan." Revista Proa - Revista de Antropologia e Arte, n. 2, v. 1, 2010.

SMITH, Bonnie G. Gênero e História: homens, mulheres e prática histórica. Bauru, SP: EDUSC, 2003.

SOUZA, Gilda de Mello e. O espírito das roupas: a moda no século dezenove. São Paulo: Companhia das Letras, 1987.

\section{Fontes documentais}

ALMEIDA, Júlia Lopes de. O Caminho do Bem. Documento autógrafo inédito. Campinas, 1883.

. "A alma das flores." In: Ânsia eterna. Rio de Janeiro: H. Garnier, 1903. . "Esperando..." In: . Ânsia eterna. Rio de Janeiro: H. Garnier, 1903. "O caso de Ruth." In: . Ânsia eterna. Rio de Janeiro: H. Garnier, 1903. "In Extremis." In: H. Garnier, 1903.

. Ânsia eterna. Rio de Janeiro:

1118 Estudos Feministas, Florianópolis, 21(3): 1099-1119, setembro-dezembro/2013 
"Floricultura." In:

Livro das Noivas. Rio de

Janeiro: Livraria Francisco Alves, 1914 (1896).

"Educação." In: Livro das Noivas. Rio de

Janeiro: Livraria Francisco Alves, 1914 (1896).

"A Mulher Brasileira." In:

. Livro das donas e

donzelas. Rio de Janeiro: Francisco Alves, 1906.

"Por quê?" In:

Livro das donas e donzelas. Rio

de Janeiro: Francisco Alves, 1906.

"Flores." In:

. Livro das donas e donzelas. Rio

de Janeiro: Francisco Alves, 1906.

. Memórias de Marta. Pesquisa, organização, cronologia

e introdução de Rosane Saint-Denis Salomoni. Florianópolis:

Editora Mulheres, 2007 [1889].

Correio da roça. Romance epistolar. Rio de Janeiro:

Presença Edições, 1987 [1913].

[Recebido em 29 de janeiro de 2012,

reapresentado em 30 de maio de 2012

e aceito para publicação em 13 de junho de 2013]

Júlia Lopes de Almeida Dramaturgic: Some Notes on Her Unpublished Play 'O
Caminho do Bem' [Path to the Goodness]
Abstract: Considered one of the foremost exponent prose writers of the "tropical belle époque",
and in spite of the literary genre in which she has earned reputation, Júlia Lopes de Almeida
(1862-1934) has revealed herself as a writer of an undeniable artistic versatility. Thus, her explorations
on the Dramatic Arts seem to be an unequivocal example: besides the published works A Herança
(1909) and Teatro (1917), the writer has left around a dozen unpublished and unstaged dramaturgical
texts, all of them available as handwritten and/or typed manuscripts, in her private archives,
which have been maintained by Claudio Lopes de Almeida, her grandson. Bearing in mind the
extension of her legacy, and considering the liaisons between art and gender/sex, this article
pursues to analyze the dramaturgical text entitled "O Caminho do Bem". Our purpose is to
contribute not only to the critical fortune of the writer, but also to those studies which have been
dedicating themselves to paving the overshadowed gaps still inscribed in the field of the Brazilian
literary historiography.
Key Words: Júlia Lopes de Almeida; Unpublished Manuscripts; Brazilian Literature; Dramatic Key Words: Júli
Arts; Gender. 